\title{
Vzdělávání osob v oblasti ICT ve výkonu trestu odnětí svobody a jeho finanční aspekty $v$ rámci politiky zaměstnanosti $v$ České republice Education of Persons in ICT in the Execution of a Custodial Sentence and its Financial Aspects in the Context of Employment Policy in the Czech Republic
}

DAGMAR KRAUSOVÁ'

\begin{abstract}
Abstrakt
Cílem príspěvku je představení souvislostímezi vzděláváním osob plnoletých a pravomocně odsouzených $\mathrm{k}$ výkonu trestu odnětí svobody ${ }^{2} \mathrm{v}$ oblasti ICT ${ }^{3}$ a využitím nabytých znalostí u těchto osob po jejich propuštění na svobodu s dopadem na finanční aspekt v rámci politiky zaměstnanosti. Príspěvek obsahuje data získaná z rozsáhlého kvantitativního průzkumu, který byl prováděn ve dvanácti českých věznicích, určených k výkonu trestu odnětí svobody osob plnoletých a pravomocně odsouzených, na podzim roku 2019. Výzkumný vzorek čítá 548 respondentů, z čehož tvoří 448 osob muži a 100 osob ženy. Součástí průzkumu byly otázky vztahující se k využívání informačních a komunikačních technologií - ICT - při páchání trestné činnosti. Data publikovaná v tomto př́spěvku doposud nebyla uceleně veřejně prezentována.
\end{abstract}

\section{Klíčová slova}

financování, ICT, kvantitativní průzkum, respondent, trest odnětí svobody, vzdělávání

\section{Abstract}

The aim of the paper is to present the connection between the education of personalities of adults and legally convicted prisoners in the field of ICT imprisonment and the use of acquired knowledge of these persons after their release with an impact on the financial aspect of unemployment policy. I rely on data obtained from an extensive quantitative survey conducted in twelve prisons in the Czech Republic, intended for the execution of imprisonment of adults and genuine convicts, in the autumn of 2019. Research sample of 548 respondents, of which 448 were men and 100 females. The survey also included

1 Mgr. Dagmar Krausová, DiS., absolventka magisterského oboru Kriminalisticko-právní specializace VŠFS, studentka doktorského programu VŠFS

2 Trest odnětí svobody je jedním z druhu trestü, který je ukládán soudem pachateli za spáchaný trestný čin. Český trestní zákoník (zákon č. 40/2009 Sb.). Druhy trestů jsou definovány v § 52 tohoto zákona.

3 Pod pojmem informační a komunikační technologie (ICT) rozumíme veškeré informační technologie používané nejen pro komunikaci, ale také pro práci s informacemi. Původní koncept informačních technologií (IT) byl následně rozšíren i o prvek komunikace. A to v okamžiku, kdy mezi sebou začaly komunikovat. 
issues related to the use of information and communication technologies - ICT - in criminal offenses. So far, the data published in this paper have not been comprehensively publicly presented, yet.

\section{Key words}

financing, ICT, quantitative research, respondent, imprisonment, education

DOI

http://dx.doi.org/10.37355/fvpk-2021/2-07

\section{Úvod}

Cílem příspěvku je zmapovat vzdělávání osob ve výkonu trestu především v oblasti ICT a jeho finanční aspekty $v$ rámci politiky zaměstnanosti. Koncentruji se na oblast výkonu trestu odnětí svobody, jehož exekuce je v České republice primárně zastřešována zejména dvěma institucemi, a to Vězeňskou službou České republiky a Probační a mediační službou České republiky, s následným přepadem do finanční oblasti. Protože i v penitenciaristice a penologii je potřeba velmi důsledně připravovat a sledovat rozpočty, a to jak na straně př́ijmů, tak na straně výdajů.

V tomto příspěvku je primárně vycházeno z rozsáhlého kvantitativního průzkumu, který byl realizován $v$ rámci praktické části diplomové práce na téma Vliv vzdělání na trestnou činnost ve čtvrtém čtvrtletí roku 2019 (Krausová, 2020). Respondenti byli vybráni náhodně, bez předchozího škálování, jedinou podmínkou pro účast v průzkumu bylo dosažení věku 18 let, pravomocné odsouzení a s ním spojený pobyt ve výkonu trestu odnětí svobody. Průzkum přináší informace z oblasti páchání trestné činnosti s využitím informačních a komunikačních technologií (počítače, mobilního telefonu a podobně). Při průzkumu byli respondenti dotazováni, zdali k páchání své trestné činnosti informační a komunikační technologie využívali, at' už př́mo, nebo alespoň částečně, jaký je jejich vztah k technologiím i v době výkonu trestu a jaké jsou možnosti vzdělávání se $v$ této oblasti v podmínkách českého vězeňství. V návaznosti na průzkum jsou v príspěvku rovněž řešeny otázky, zdali mají osoby pravomocně odsouzené k trestu odnětí svobody, toho času ve výkonu trestu, muži i ženy, v České republice, bez dalšího požadavku na škálování, dostatečný prostor na vzdělávání se v oblasti informačních a komunikačních technologií? Využívalo při páchání trestné činnosti aktivně informační a komunikační technologie $20 \%$ dotázaných, tedy osob pravomocně odsouzených k trestu odnětí svobody, toho času ve výkonu trestu, muži i ženy, v České republice, bez dalšího požadavku na škálování? Získávalo inspiraci k páchání trestné činnosti na internetu a sociálních sítích nejméně $30 \%$ dotázaných, tedy osob pravomocně odsouzených k trestu odnětí svobody, toho času ve výkonu trestu, muži i ženy, v České republice, bez dalšího požadavku na škálování?

Informace získané z uvedeného průzkumu jsou následně rozpracovány do samostatné oblasti vzdělávání v oblasti výkonu trestu v oblasti ICT z pohledu jeho finančního pojetí, z nějž je zřejmé, zdali jsou tyto investice efektivní v návaznosti na další život osob 
propuštěných z výkonu trestu odnětí svobody, zdali budou mít jejich znalosti v oblasti ICT, nabyté v rámci oficiálních vzdělávacích aktivit ve výkonu trestu odnětí svobody pozitivní dopad na jejich následné začlenění zpět do společnosti, zdali je aktivně využijí při zapojení se do pracovního procesu. A to z toho důvodu, že ICT je jednou z nejdynamičtěji se rozvíjejících oblastí celosvětově. Bez alespoň elementární znalosti informačních a komunikačních technologií je v dnešní době uplatnitelnost na trhu práce prakticky nulová.

\section{Popis problematiky vzdělávání osob ve výkonu trestu odnětí svobody}

Recidiva je v České republice na velmi vysoké úrovni, do vězení se vrací sedm z deseti propuštěných, což znamená, že se do vězení vrátí $70 \%$ propuštěných (SARPO, 2018). Snížení recidivy by znamenalo nejen zvýšení bezpečnosti ve společnosti, ale i úsporu nákladů daňových poplatníků na policii, justici či vězeňství apod. Až $60 \%$ odsouzených nemá stabilní bydlení a $90 \%$ přiznává, že má dluhy, z toho $73 \%$ je není schopno splácet (SARPO, 2018). V USA se do pěti let po propuštění vrací do výkonu trestu dokonce $76 \%$ bývalých vězňů (Smith, 2020). Rozšiření ICT vzdělávání ve věznicích má mít za cíl snižit recidivu. Bohužel je problematické technologie vězňům v plném rozsahu v rámci výuky zpřistupnit z bezpečnostních důvodů (Pike, 2015). V českých věznicích internet $k$ dispozici je, ale př́stup k němu mají pouze vyučující, kteří pro potřeby výuky vyhledají potřebné informace a ty pak promítají přes projektor studentům - vězňům (Šámal, 2019). Volný př́stup k internetu je vězňùm zapovězen také například v USA, Anglii či Austrálii (Smith, 2020).

Znalosti v oboru ICT se dnes prolínajíjiž téměř všemi pracovními profesemi - od operátora CNC stroje až po pokladní v supermarketu. Každý z nich pro výkon své profese potřebuje alespoň základní znalost práce s informační a komunikační technikou. V USA je až na $90 \%$ pracovních míst kladen požadavek na různou úroveň znalostí práce s ICT. Tento trend je od roku 2011 pozorován u více než 500 profesí, u nichž dríve znalost práce s technologiemi nebyla potřebná (Muro et al., 2017). Cowen (2013) dokonce poukazuje na to, že alespoň základní znalost ICT je dnes nutná při výkonu jakéhokoliv zaměstnání kdekoliv na světě. Proto již některé země začlenily do výukových programů ve věznicích ICT kurzy, např́klad Dánsko, Norsko, Anglie, USA, Austrálie (Smith, 2020), ale také Česká republika, i když zatím jen velmi okrajově (VS ČR, 2019). Zhruba 60 procent lidí bez práce v České republice má pouze základní či střední vzdělání bez maturity, u osob ve výkonu trestu je toto procento ještě vyšší, a to více než $4 / 5$, přesně toto číslo činilo v součtu v roce 2019 81,25\% (Vězeňská služba ČR, 2019). Odborníci na vzdělávání ve věznicích v USA se domnívají, že efektivní vzdělávání v oblasti ICT by mohlo snížit recidivu a současně zvýšit šance na zaměstnatelnost vězněných osob po jejich propuštění. Za nejdůležitější považují získání základních znalostí práce s informační a komunikační technikou, a to jak s hardwarem, tak softwarem, klíčová je alespoň elementární uživatelská znalost programů Microsoft Office (Beblabý et al., 2016). Aby mohlo k takovému procesu dojít, je nutná změna vězeňské organizační kultury od přístupu založeného na trestech k rehabilitačnímu př́stupu. Tím by bylo možné upřednostnit vzdělávací programy a zvýšit šance na sociální integraci vězňů po propuštění a omezit recidivu (Smith, 2020). 
Dokumentem, který navazuje na poznatky z oboru vězeňství v České republice, je Nová koncepce vězeňství do roku 2025. Jedná se o historicky první systémovou aktivitu, která pojímá vězeňství v širším pojetí neomezeném pouze na Vězeňskou službu České republiky. Sestaven byl široký tým z téměř padesátky odborníků z Ministerstva spravedlnosti České republiky, Vězeňské služby České republiky, Probační a mediační služby, ministerstev a dalších institucí, včetně čtyř organizací akademických a nestátních. Cílem Koncepce je co nejširší zohlednění portfolia aspektů problematiky vězeňství. Nová Koncepce vězeňství do roku 2025 pojímá vzdělávání jako jeden z prostředků naplnění hlavních zásad výkonu trestu odnětí svobody uvedených v $§ 2$ zákona o výkonu trestu odnětí svobody č. 169/1999 Sb. Současně vnímá vzdělání jako nástroj k získání a zvyšování pracovních dovedností. Ty mají odsouzenému pomoci zvýšit šanci na úspěch na trhu práce, a získat tak kvalifikované pracovní místo, což přesahuje samozřejmě do sociálního postavení člověka a pomáhá mu tak řešit také ekonomickou situaci po návratu do běžného života. Koncepce pohlíží na vzdělání a vzdělávání opravdu velmi seriózně a důkladně rozpracovává projekt edukace ve věznicích. Uvádí, že vzdělání představuje jeden z nejdůležitějších resocializačních nástrojů. Proto je pro každou vězněnou osobu vypracován individuální vzdělávací plán, byt’ pro některé jen $v$ základní podobě. Judikatura věznicím obecně ukládá vytvářet podmínky pro to, aby odsouzení mohli získat a zvyšovat svou pracovní kvalifikaci a rozšiřovat si svoji všeobecnou informovanost. Tato povinnost je dále rozvedena § 34 zákona č. 169/1999 Sb. tak, že odsouzeným, u nichž jsou pro to předpoklady, se umožní, aby získali vzdělání na základní nebo i střední škole, anebo se zúčastnili dalších forem vzdělávání, díky kterým získají vyšší pracovní kvalifikaci. Vzdělávání vězněných osob je možno rozdělit podle kritéria formálnosti na formální a neformální. Formální vzdělávání zajištuju sama Vězeňská služba nebo spolupracující subjekt a jeho výsledkem je základní, středoškolské, vyšší odborné nebo i vysokoškolské vzdělání, tedy doklad o dosaženém vzdělání uplatnitelný na trhu práce (MSp ČR, 2016).

Vzdělávání odsouzených není výdobytkem posledních let. Složení maturitní zkoušky ve věznici je ale administrativně složitým úkonem, protože středisko nemá akreditaci k vydávání maturitních zkoušek. Musí proto spolupracovat s civilní školou - garantem. $\checkmark$ praxi to funguje tak, že se otázky přivezou v zapečetěné bedně, která prochází na bráně rentgenem, dále je doprovázena strážným, v jeho př́tomnosti ji předseda zkušební komise otevře a strážný opět zkontroluje. Neformální vzdělávání probíhá v rámci programu zacházení a může se napríklad jednat o všeobecné vzdělávací kurzy, odborné kurzy, rekvalifikační kurzy, specializační kurzy a podobně. Kurz bývá velmi často, stejně jako formální vzdělávání, zakončen dokladem o jeho absolvování (MSp ČR, 2016).

Statistiky Českého statistického úřadu ukazují, že počet odsouzených, kteří získali osvědčení o zaškolení nebo kvalifikační průkazy či výuční listy, dlouhodobě klesá (Čsú, 2019). Zatímco $v$ roce $v$ roce 2010 získalo osvědčení o zaškolení nebo kvalifikační průkaz 927 osob, v roce 2017 jich bylo o více než padesát procent méně, a to 406. Stejný trend sledujeme s odkazem na uvedené statistiky také u výučních listů. Zde je však propad o něco nižší, kdy v roce 2010 získalo výuční list 261 vězněných osob, kdežto o sedm let později to bylo jen 170 (ČSÚ, 2019). 
Graf 1: Výsledky v odborném vzdělávání odsouzených 2010-2017

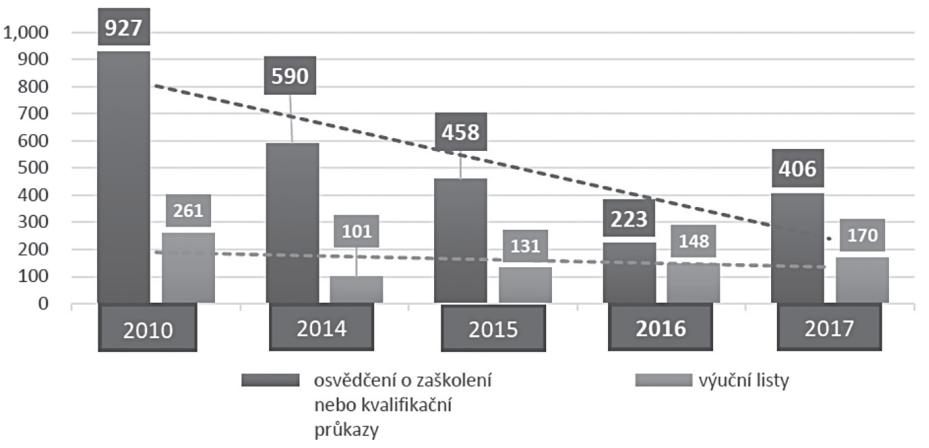

Zdroj: Vlastní konstrukce na základě dat Čsú, 2019

\section{Náklady na nezaměstnaného v České republice}

Nezaměstnanost představuje jeden z nejvýznamnějších a nejsledovanějších reálných ukazatelů stavu ekonomiky. Obyvatelstvo v produktivním věku se dělí na tři skupiny, a to na osoby, které mají práci - zaměstnaní, osoby, které nemají zaměstnání a aktivně ji hledají - nezaměstnaní. Tyto dvě skupiny společně tvoří pracovní sílu. Lidé, kteří práci nemají, ale ani ji aktivně nehledají - mimo pracovní sílu, nejsou ekonomicky aktivní. Snahou státu je proti nezaměstnanosti bojovat. Prostřednictvím tak zvané aktivní politiky zaměstnanosti, národních podpor a dalších instrumentů hraje důležitou roli míra nezaměstnanosti. Tou se rozumí podíl nezaměstnaných na pracovní síle, neboli počet nezaměstnaných vydělený ekonomicky aktivním obyvatelstvem. ${ }^{4}$

Tab. 1: Struktura uchazečů o zaměstnání podle délky nezaměstnanosti

\begin{tabular}{|c|c|c|c|c|c|c|}
\hline & \multicolumn{2}{|c|}{ k 31. 12. 2018} & \multicolumn{2}{|c|}{ k 31. 12. 2019} & \multicolumn{2}{|c|}{ meziroční rozdíl } \\
\hline & $\mathrm{v}$ tis. & $v \%$ & $v$ tis. & $v \%$ & $v$ tis. & $v \%$ \\
\hline $\begin{array}{l}\text { Uchazeči celkem } \\
\text { v tom: }\end{array}$ & 231,5 & 100,0 & 215,5 & 100,0 & $-16,0$ & $-6,9$ \\
\hline do 3 mèsíců & 96,2 & 41,6 & 94,0 & 43,6 & $-2,2$ & $-2,3$ \\
\hline 3-6 měsíců & 42,1 & 18,2 & 44,1 & 20,5 & 2,0 & 4,8 \\
\hline 6-9 měsíců & 20,1 & 8,7 & 20,0 & 9,3 & $-0,1$ & $-0,5$ \\
\hline 9-12 měsíců & 12,6 & 5,4 & 12,6 & 5,8 & 0,0 & 0,0 \\
\hline 12-24 měsíců & 19,6 & 8,5 & 18,1 & 8,4 & $-1,5$ & $-7,7$ \\
\hline nad 24 měsíců & 40,9 & 17,7 & 26,7 & 12,4 & $-14,2$ & $-34,7$ \\
\hline nad 5 mèsíců & 103,5 & 44,7 & 88,5 & 41,1 & $-15,0$ & $-14,5$ \\
\hline nad 6 mèsíců & 93,3 & 40,3 & 77,4 & 35,9 & $-15,9$ & $-17,0$ \\
\hline nad 12 měsíců & 60,5 & 26,1 & 44,8 & 20,8 & $-15,7$ & $-26,0$ \\
\hline
\end{tabular}

Pozn.: drobné odchylky součtu osob v jednotlivých kategorilch od uvedeného celkového počtu souvisí se zaokrouhlením hodnot na jedno desetinné místo

Zdroj: MPSV ČR, 2019

4 Oficiální míra nezaměstnanosti obvykle plně nepopisuje skutečnou nezaměstnanost. Tu zkreslují hlavně dvě skutečnosti. Oficiální míra nezapočítává zaměstnance, kteři pracují na zkrácený pracovní úvazek. Dále nereflektuje znechucené nezaměstnané (odrazené pracovníky), kteři po neúspěších v hledání vhodného zaměstnání přestali aktivně shánět práci. 
Při posuzování efektů (aktivní) politiky zaměstnanosti je nutné hodnotit také potenciální ekonomický dopad ve smyslu jeho efektivity a hospodárnosti. Proto je důležité vzájemně porovnat vynakládané výdaje na opatření a nástroje politiky zaměstnanosti s finančními dopady, které nezaměstnanost společnosti přináší. Doporučuje se proto kvantifikovat dopady jedné nezaměstnané osoby na veřejné rozpočty. Vznik nezaměstnanosti nejenom souvisí s přímou výplatou podpory v nezaměstnanosti, potažmo jiných sociálních dávek, ale rovněž se negativně projevuje na př́immové stránce veřejných rozpočtů $v$ podobě nevybraného pojistného a daní a v neposlední řadě $v$ podobě snížení koupěschopnosti nezaměstnané osoby a s tím souvisejícího snížení objemu jejího spotřebního koše. To má za následek sekundárně opět snížení výběru daní (např. DPH) a celkově snižuje ekonomický potenciál. Kvantifikace dopadů nezaměstnanosti jedné osoby na ekonomiku, zejména na veřejné rozpočty, je však s ohledem na svoji komplexnost velice obtížná. Na úrovni jednotlivce hrají roli zejména jeho vlastní charakteristiky, jako je věk, vzdělání, původní, resp. potenciální, zaměstnání (příjem), předpokládaná doba nezaměstnanosti, a to v kontextu širší hospodářské situace (recese x konjunktura) (MPSV ČR, 2019).

V roce 2016 si MPSV ČR nechalo VÚPSV vypracovat studii s názvem Odhad nákladů veřejných rozpočtů vynakládaných na jednoho nezaměstnaného. $Z$ této studie, jejiž závěry využívá MPSV ČR dodnes (2021), plyne, že dopady do veřejných rozpočtů jsou vyčísleny na cca 207000 Kč ročně na jednu nezaměstnanou osobu. V této částce jsou zahrnuty jak př́mé výdaje státu (podpory, sociální dávky), tak významnou část tvoří výpadky veřejných financí v důsledku nevybraných daní a odvodů. Ne všechny výpadky a výdaje veřejných rozpočtů souvisejících s nezaměstnaností lze aplikovat na osoby dlouhodobě nezaměstnané. Především výdaje na politiku zaměstnanosti není možno dát do prímé souvislosti s náklady na dlouhodobě nezaměstnané osoby, jelikož osoby evidované déle než 12 měsíců zpravidla nepobírají podporu v nezaměstnanosti ${ }^{5}$ a rovněž výdaje na aktivní politiku zaměstnanosti (APZ) nelze považovat za výdaje negativní (Jahoda, Godarová, 2016).

Graf 2: Náklady na jednoho nezaměstnaného v ČR v letech 2005-2019

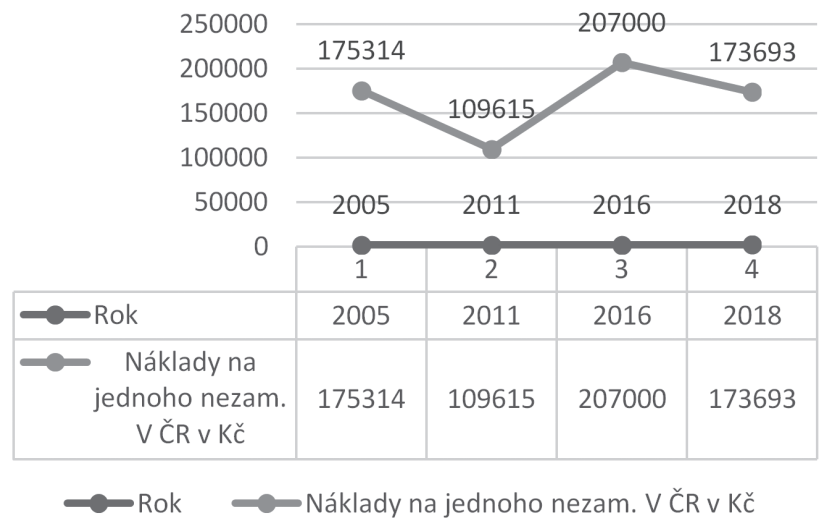

Zdroj: Vlastní konstrukce, zpracováno na základě podkladů ČSÚ, MPSV, 2020

5 Ke dni 30. 6. 2018 bylo déle než 12 měsíců evidováno pouze 1 \% uchazečů pobírajících podporu v nezaměstnanosti. 


\section{Interpretace výzkumu}

\section{Metoda průzkumu}

Z důvodu shromáždění většího počtu odpovědí, vzhledem k vypovídající hodnotě projektu, byla jako nejvhodnější vybrána metoda kvantitativního výzkumu, technikou dotazníkového šetření. Kvantitativní průzkum je založen na testování výzkumných otázek (hypotéz), tedy jejich potvrzení či vyvrácení. Využívá kvantifikační či statistické metody. Sběr dat je strukturovaný a probíhá zpravidla pomocí dotazníků, testů či nezúčastněného pozorování (Olecká, Ivanová, 2010).

\section{Metodika sběru dat}

Po konzultaci s hlavním psychologem vězeňské služby PhDr. Václavem Jiřičkou, Ph.D. byly vybrány věznice např́č celou Českou republikou vhodné k zapojení do projektu, celkem šestnáct. S žádostí o spolupráci bylo osloveno emailovou cestou šestnáct ředitelů věznic. Do projektu se zapojilo dvanáct věznic, deset mužských a dvě ženské, s rưzným stupněm zabezpečení. $Z$ pohledu množství zapojených věznic se mi tak podařilo do projektu zapojit téměř polovinu - $48 \%$ - z celkového počtu 25 věznic určených $k$ výkonu trestu odnětí svobody osob pravomocně odsouzených, plnoletých, v České republice. Z hlediska následné práce s daty se jedná o dostatečně velký reprezentativní vzorek - 548 (muži 448 / ženy 100) k získání ucelených závěrů, s nimiž je možno dále pracovat a hodnotit je jako validní.

Tab. 2: Věznice zapojené do kvantitativního průzkumu (záŕí-listopad 2019)

\begin{tabular}{|c|c|c|c|}
\hline Věznice & Stupeň zabezpečení ${ }^{6}$ & Ženy & Muži \\
\hline Bělušice & s ostrahou & & $x$ \\
\hline Jiřice & s ostrahou & & $x$ \\
\hline Kynšperk nad Ohří & s dozorem & & $\mathrm{x}$ \\
\hline Odolov & s dozorem & & $x$ \\
\hline Opava & s dozorem & $x$ & \\
\hline Ostrov & s dozorem & & $x$ \\
\hline Pardubice & s ostrahou & & $x$ \\
\hline Příbram & s ostrahou a dozorem & & $x$ \\
\hline Rapotice & s ostrahou & & $x$ \\
\hline Světlá n. Sázavou & s dozorem & $\mathrm{x}$ & \\
\hline Vinařice & s ostrahou & & $x$ \\
\hline Všehrdy & s dozorem & & $x$ \\
\hline
\end{tabular}

Zdroj: Vlastní konstrukce na základě kvantitativního průzkumu, 2019

6 https://www.vscr.cz/o-nas/zmena-vnejsi-diferenciace/obecny-postup/ 


\section{Průběh řešení úkolu - etapy výzkumného projektu}

\section{Etapa I. - tvorba dotazníku}

Kroky spojené s tvorbou dotazníku a následně s jejich distribucí do cílových míst byly předem konzultovány s odborníky, například s PhDr. Václavem Jiřičkou, Ph.D., hlavním psychologem Vězeňské služby České republiky. Definoval věznice, do nichž byly následně poslány elektronickou poštou žádosti o spolupráci na průzkumu, adresovány prímo ředitelům zařízení. Dalšími konzultanty projektu byli specialisté z oblasti marketingových průzkumů, paní Ing. Hana Kloučková, majitelka a ředitelka výzkumné agentury Confess Research, a zaměstnanec Národní centrály organizovaného zločinu z oddělení kyberkriminality, který nedal souhlas $s$ uvedením svého jména z bezpečnostních důvodů. Díky tomu bylo možno sjednotit terminologii hlavně v oblasti informačních a komunikačních technologií. Cílem konzultací bylo sestavit dotazník tak, aby bylo možno získat co nejvyužitelnější a nejrelevantnější data, ale také jej připravit srozumitelně pro respondenty, aby byli schopni jasně a samostatně odpovědět na položené otázky.

\section{Testovací fáze průzkumu}

Před distribucí dotazníků přímo respondentům proběhla testovací fáze. Přibližně dvě desítky formulářu byly rozdány za účelem získání zpětné vazby, zda respondenti porozumí otázkám. V návaznosti na jejich odpovědi byl následně dotazník zpracován do finální podoby.

\section{Etapa II. - distribuce a sběr dotazníků}

Následně byly dotazníky do věznic, vždy po předchozí dohodě s řediteli jednotlivých zařízení, doručeny prostřednictvím České pošty. Stejnou formou byly navráceny. Dotazník byl zcela anonymní a sloužil k potvrzení či vyvrácení stanovených hypotéz. Cílem bylo získat v každé z oslovených věznic co nejvíce vyplněných dotazníků zpět, bez jakéhokoliv škálování respondentů a zajistit tak co nejširší diverzitu odpovědí. Počet dotazníků na věznici se pohyboval v rozmezí 30-50 kusů a jejich návratnost byla více než $90 \%$. Z 580 distribuovaných dotazníků se vrátilo 548, tedy $94 \%$. Respondenti dotazníky vyplňovali samostatně a anonymně.

\section{Etapa III. - vyhodnocení dotazníků}

Po doručení vyplněných dotazníků zpět bylo nutné převést je do digitální podoby. Pro převedení do elektronické podoby byla využita aplikace dostupná zdarma, Google dotazník. Následné vyhodnocení dat probíhalo v licencovaném programu Microsoft Office Excel. Produkt Microsoft byl vybrán kvưli přehlednější práci s daty a širším možnostem při 
sestavování grafů. Data byla kombinována a křižena tak, aby z nich bylo možno dále čerpat informace k daným hypotézám.

\section{Problémy při sběru dat}

Vzhledem $\mathrm{k}$ tomu, že průzkum probíhal napříč vězeňskými zařízeními v celé České republice, bylo potřeba vedení každé $z$ nich individuálně oslovit, případně následně navštívit a projekt představit, proto byla největším úskalím časová tíseň, a to i přesto, že výzkum probíhal dva roky dle předem sestaveného projektového plánu. Další úskalí bylo shledáno $v$ odpovědích respondentů. $V$ návaznosti na osobní rozhovory s príslušníky Vězeňské služby mají vězni ambice „dělat se lepšími“ a zkreslovat informace.

\section{Analýza skupiny respondentů}

Respondenti byli vybráni náhodně, bez předchozího škálování, jedinou podmínkou pro účast v průzkumu bylo pravomocné odsouzení a s ním spojený pobyt ve výkonu trestu odnětí svobody v zařízení specifikovaném výše.

Tab. 3: Analýza respondentů průzkumu

\begin{tabular}{|l|c|r|r|r|r|r|}
\hline \multicolumn{1}{|c|}{ Věk } & Počet celkem & \multicolumn{1}{c|}{$\%$} & \multicolumn{1}{c|}{ Muži } & \multicolumn{1}{c|}{$\%$} & Ženy & \multicolumn{1}{c|}{$\%$} \\
\hline $\mathbf{1 8 - 2 5}$ & 89 & 16,0 & 71 & 16,0 & 18 & 18 \\
\hline $\mathbf{2 6 - 3 5}$ & 233 & 43,0 & 192 & 43,0 & 41 & 41 \\
\hline $\mathbf{3 6 - 4 5}$ & 132 & 24,0 & 107 & 24,0 & 25 & 25 \\
\hline $\mathbf{4 6 - 5 5}$ & 76 & 14,0 & 62 & 14,0 & 14 & 14 \\
\hline $\mathbf{5 6 - 6 5}$ & 14 & 3,0 & 12 & 3,0 & 2 & 2 \\
\hline $\mathbf{6 6 - 7 5}$ & 2 & 0,5 & 2 & 0,5 & 0 & 0 \\
\hline $\mathbf{7 6 - v i ́ c e ~}$ & 2 & 0,5 & 2 & 0,5 & 0 & 0 \\
\hline Celkem & 548 & 100,0 & 448 & 100,0 & 100 & 100 \\
\hline
\end{tabular}

Zdroj: Vlastní konstrukce na základě kvantitativního průzkumu, 2019

Tab. 4: Vzdělávání respondentů ve výkonu trestu odnětí svobody

\begin{tabular}{|l|r|r|r|r|r|r|}
\hline & Celkem & \multicolumn{1}{c|}{$\%$} & Muži & \multicolumn{1}{c|}{$\%$} & Ženy & $\%$ \\
\hline Zájmový kroužek & 43 & 31 & 35 & 28 & 8 & 47 \\
\hline Rekvalifikace & 62 & 44 & 55 & 44 & 7 & 41 \\
\hline Výuční list & 34 & 24 & 32 & 26 & 2 & 12 \\
\hline Střední škola & 2 & 1 & 2 & 2 & 0 & 0 \\
\hline Celkem & 141 & 100 & 124 & 100 & 17 & 100 \\
\hline
\end{tabular}

Zdroj: Vlastní konstrukce na základě kvantitativního průzkumu, 2019 
Jako nejčastější vzdělávací aktivitu ve výkonu trestu odnětí svobody uvádí respondenti rekvalifikaci $44 \%$ (62 ze 141), následují zájmové kroužky 31 \% (43 ze 141). Téměř čtvrtina respondentů - $24 \%$ (34 ze 141) se ve výkonu trestu odnětí svobody snaží získat výuční list a pouze $1 \%$ ( 2 ze 141) studuje střední školu zakončenou maturitní zkouškou. Podíváme-li se na genderové rozložení, pak se častěji vzdělávacím programům ve výkonu trestu odnětí svobody věnují muži, a to $28 \%$ (124 ze 448), ženy pak $17 \%$ (17 ze 100). Zatímco muži nejčastěji absolvují rekvalifikaci $44 \%$ (55 ze 124), ženy navštěvují zájmové kroužky $47 \%$ (8 ze 17). Muži se také častěji snaží získat výuční list $26 \%$ (32 ze 124), ženy $12 \%$ ( 2 ze 17).

Graf 3: Možnost vzdělávání se v oblasti ICT ve výkonu trestu - muži + ženy

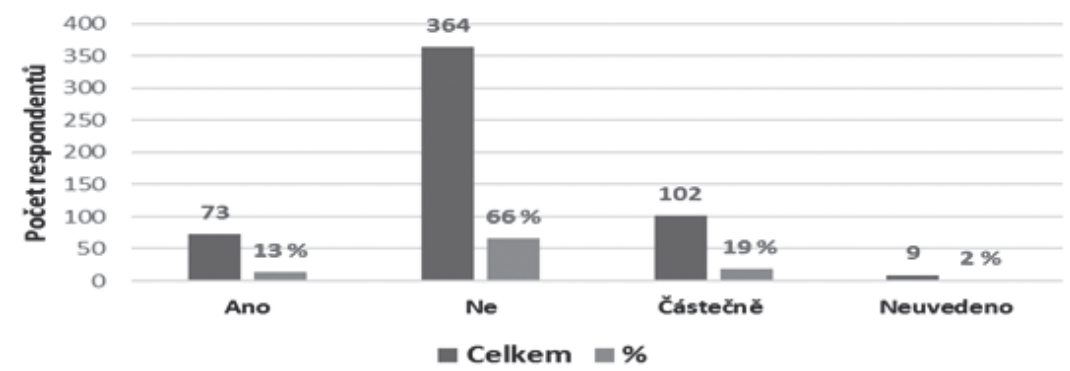

Zdroj: Vlastní konstrukce na základě kvantitativního průzkumu, 2019

S odkazem na průzkum $13 \%$ (73 z 548) respondentů uvádí, že má ve výkonu trestu př́ležitost vzdělávat se $v$ oblasti informačních a komunikačních technologií. Jedná se o $15 \%$ (66 ze 448) mužů a $7 \%$ (7 ze 100) žen. Příležitost k částečnému vzdělávání pak uvádí 19\% (102 z 548) respondentů, $17 \%$ (79 ze 448) mužů a $23 \%$ (23 ze 100) žen. 497 z 548 (91\%) respondentů však současně uvádí, že po propuštění z výkonu trestu nebude mít s používáním ICT (například počítač, mobilní telefon a podobně) problém a bude je aktivně využívat $v$ běžném životě. Taktéž bude bez problémů využívat informační a komunikační technologie a používat je $v$ běžném životě (např. chytrý telefon, počítač atd.). Potvrzuje se, že osoby pravomocně odsouzené k trestu odnětí svobody, toho času ve výkonu trestu, muži i ženy, v České republice, bez dalšího požadavku na škálování, nemají ve výkonu trestu odnětí svobody dostatečný prostor na vzdělávání se v oblasti informačních a komunikačních technologií.

\section{Využívání ICT při páchání trestné činnosti}

Kybernetická kriminalita, ${ }^{7}$ dřive také označována jako informační kriminalita, je definována Policií České republiky jako trestná činnost, která je páchána v prostředí informačních a komunikačních technologií včetně počítačových sítí. Samotná oblast informačních a komunikačních technologií je bud' předmětem útoku, nebo je páchána trestná činnost

7 Termín "kybernetická kriminalita" je odvozován od pojmu kybernetický prostor, případně zkráceně kyberprostor. Jedná se o virtuální prostředí, které nemá začátek ani konec. Nezná hranice národních států a nelze určit jeho rozsah. 
za výrazného využití informačních a komunikačních technologií jakožto významného prostředku k jejímu páchání.

Tab. 5: Aktivní využívání ICT při páchání trestné činnosti - muži + ženy

\begin{tabular}{|l|c|r|r|r|r|r|}
\hline & Celkem & $\%$ & Muži & \multicolumn{1}{c|}{$\%$} & Ženy & $\%$ \\
\hline Ano & 221 & 41 & 185 & 41 & 36 & 36 \\
\hline Ne & 320 & 58 & 258 & 58 & 62 & 62 \\
\hline Neuvedeno & 7 & 1 & 5 & 1 & 2 & 2 \\
\hline Celkem & 548 & 100 & 448 & 100 & 100 & 100 \\
\hline
\end{tabular}

Zdroj: Vlastní konstrukce na základě kvantitativního průzkumu, 2019

Z průzkumu plyne, že $41 \%$ ( 221 z 548) respondentů uvádí, že k páchání trestné činnosti aktivně využívalo ICT (například počítač, mobilní telefon a podobně). Dle odpovědí respondentů častěji využívali informační a komunikační technologie muži 41 \% (185) a $36 \%$ (36) ženy. Procentuální rozdíl činí $5 \%$. Nepotvrzuje se, že při páchání trestné činnosti aktivně využívalo informační a komunikační technologie $20 \%$ dotázaných, tedy osob pravomocně odsouzených k trestu odnětí svobody, toho času ve výkonu trestu, muži i ženy, v České republice, bez dalšího požadavku na škálování.

Tab. 6: Hledání inspirace k páchání trestné činnosti na internetu a sociálních sítích

\begin{tabular}{|l|r|r|r|r|r|r|}
\hline & Celkem & \multicolumn{1}{c|}{$\%$} & Muži & $\%$ & Ženy & $\%$ \\
\hline Ano & 21 & 4 & 15 & 3 & 6 & 6 \\
\hline Ne & 450 & 82 & 387 & 87 & 63 & 63 \\
\hline Částečně & 68 & 12 & 40 & 9 & 28 & 28 \\
\hline Neuvedeno & 9 & 2 & 6 & 1 & 3 & 3 \\
\hline Celkem & 548 & 100 & 448 & 100 & 100 & 100 \\
\hline
\end{tabular}

Zdroj: Vlastní konstrukce na základě kvantitativního průzkumu (2019)

Z průzkumu plyne, že inspiraci k páchání trestné činnosti na internetu a sociálních sítích získávala $4 \%$ ( 21 z 548) respondentů, částečně $12 \%$ (68 z 548) respondentů. Inspiraci k páchání trestné činnosti na internetu a sociálních sítích nehledalo 82 \% (450 z 548) dotázaných. Častěji se k inspiraci k páchání trestné činnosti na internetu a sociálních sítích uchylovaly ženy, a to v $6 \%$ (6 ze 100), zatímco muži pouze ve $3 \%$ (15 ze 448). Alespoň částečnou inspiraci k páchání trestné činnosti na internetu a sociálních sítích vyhledalo $28 \%$ ( 28 ze 100) žen, zatímco pouze $9 \%$ ( 40 ze 448) mužů. Nepotvrzuje se tak, že nejméně $30 \%$ dotázaných, tedy osob pravomocně odsouzených $\mathrm{k}$ trestu odnětí svobody, toho času ve výkonu trestu, muži i ženy, v České republice, bez dalšího požadavku na škálování získávalo inspiraci k páchání trestné činnosti na internetu a sociálních sítích. Zajímavé je ovšem zjištění, že inspirace k páchání trestné činnosti ve virtuálním prostředí je spíše ženskou doménou. 


\section{Závěr}

Cílem příspěvku bylo zhodnocení efektivity vzdělávání osob ve výkonu trestu především v oblasti ICT a jeho finančních aspektů z pohledu veřejných financí. $Z$ uvedených dat je zřejmé, že přesto, že jsou informační a komunikační technologie běžnou součástí našich životů, hrají významnou roli, která navíc stále roste, i v páchání kriminality. Což ale neznamená, že každý, kdo využívá k páchání trestné činnosti ICT, dokáže s technologiemi efektivně pracovat a využít je $\mathrm{k}$ uplatnění se na trhu práce. Vzhledem $\mathrm{k}$ tomu, že dnes již téměř neexistuje na trhu práce pozice, která by v menší či větší míře nekladla požadavky na alespoň základní znalost ICT (Cowen, 2013), je zapotřebí reflektovat tento fakt také v oblasti penitenciární péče. Cílenému vzdělávání v oblasti informační a komunikační techniky $v$ českém vězeňství zatím přiliš prostoru, jak plyne z dostupných veřejných materiálů, věnováno není. To rovněž dokazují data uvedená v tomto článku, kdy pouze $13 \%$ (73 z 548) respondentů uvedlo, že má možnost se v dané oblasti ve výkonu trestu odnětí svobody vzdělávat. Což potvrzují i data Vězeňské služby ČR, kdy v roce 2019 absolvovalo ve výkonu trestu odnětí svobody PC kurz jen 100 osob z více než 19 tisíc vězňů (VS ČR, 2019). Je proto potřeba důkladněji mapovat investice a náklady vložené do tohoto segmentu a vyhodnocovat jejich efektivitu. Stejně jako apelujeme na implementaci moderních prvků do výuky na základních, středních a vysokých školách, měli bychom si být jisti, že stejný prístup bude prosazován také vůči osobám ve výkonu trestu odnětí svobody, což v podstatě reflektuje i prohlášení Rady Evropy (1990). Protože, jak plyne z uvedených dat, ale také ze zdrojů Vězeňské služby České republiky, je v produktivním věku, a to 30-40 let, majoritní část vězňů. $V$ tuto chvíli jsou náklady na jednoho vězně cca $1000 \mathrm{Kč/den}$ a v roce 2019 bylo v českých věznicích 19155 osob, což činí 19155000 Kč/den. Pokud tedy zajistíme efektivní vzdělávání vězňů v době jejich pobytu ve výkonu trestu odnětí svobody, zvýší se tím jejich uplatnitelnost na trhu práce a budou schopni hradit si, alespoň částečně, své náklady na život na svobodě. Poskytnuté vzdělávání či vzdělání získané ve výkonu trestu odnětí svobody nemá platnost pouze ve věznicích, ale i po propuštění z výkonu trestu a zvyšuje potenciální hodnotu uchazeče na trhu práce. Osoby propuštěné z výkonu trestu odnětí svobody tak dostávají větší šanci získat zaměstnání, což se rovná úsporám výdajů za nezaměstnané ze státního rozpočtu. Počítat pak dále musíme is dalšími výdaji z veřejných zdrojů po propuštění těchto osob z výkonu trestu. Náklady na jednoho nezaměstnaného v Česku jsou přibližně 207000 Kč/rok (MPSV ČR, 2016). Částka se skládá z podpory v nezaměstnanosti, státních plateb za zdravotní pojištění, ztrát z daní a odvodů za neprovedenou práci a z dalších sociálních dávek. Jde o odhady vycházející z průměrů, které nemohou přesně kvantifikovat všechny dopady nezaměstnanosti, zejména pokud se týká zdraví, psychiky, ztráty kvalifikace atd. Pokud by všech 100 osob využilo znalosti ICT získaných v kurzech ve výkonu trestu odnětí svobody, mohlo by dojít k úspoře až 20700000 Kč ze státního rozpočtu pouze v této jedné oblasti.

Tento příspěvek byl zpracován v rámci grantového projektu studentského vědeckého výzkumu s názvem „Př́stup osob pravomocně odsouzených $k$ trestu odnětí svobody k ICT vzdělávání v českých věznicích a jeho využití po propuštění na svobodu" realizovaného na Vysoké škole finanční a správní, číslo projektu 7427/2021/01. 


\section{Použitá literatura}

BEBLAVÝ, M., B. FABO and K. LENAERTS. Demand for Digital Skills in the US Market: The IT Skills Pyramide. [online]. [cit. 2021-02-13]. Path: https://www.ceps.eu/ceps-publications/ demand-for-digital-skills-in-the-us-labour-market-the-it-skills-pyramid/

COWEN, T. Average is over: Powering America beyond the age of great stagnation. New York: Dutton, 2013.

ČESKO. Zákon č. 40/2009 ze dne 8. ledna 2009, trestní zákoník. In: Sbírka zákonů České republiky.

ČESKO. Zákon č. 169/1999 ze dne 30. června 1999, o výkonu trestu odnětí svobody a o změně některých souvisejících zákonů. In: Sbírka zákonů České republiky.

DRAHÝ, F., J. HŮRKA, M. PETRAS a M. SARPO. Charakteristiky odsouzených v českých věznicích: deskriptivní studie. Praha: Vězeňská služba České republiky, 2018. ISBN 978-80-270-5197-7.

JAHODA, R. a J.GODAROVÁ, Odhad nákladů veřejných rozpočtů vynakládaných na jednoho nezaměstnaného [online]. VUPSV, Praha 2016. [cit. 10. ledna 2021]. Path: www:http:// praha.vupsv.cz/Fulltext/vz_412.pdf

KRAUSOVÁ, Dagmar. Vliv vzdělání na trestnou činnost [online]. 2020 [cit. 2021-02-01]. Path: https://is.vsfs.cz/th/kn11v/. Diplomová práce. Vysoká škola finanční a správní. Vedoucí práce Veronika Anna Polišenská.

Ministerstvo práce a sociálních věcí ČR. Analýza vývoje zaměstnanosti a nezaměstnanosti v roce 2017. Č. j.: MPSV-2018/80062-401/1.

Ministerstvo práce a sociálních věcí ČR. Odbor trhu práce a podpory výzkumu a vývoje. Analýza vývoje zaměstnanosti a nezaměstnanosti v roce 2019. Praha. 2020.

Ministerstvo práce a sociálních věcí ČR. Odbor koncepcí a strategií trhu. Strategický rámec politiky zaměstnanosti do roku 2030. Praha. 2019.

MOLNÁR, Z., S. MILDEOVÁ, H. ŘEZANKOVÁ, R. BRIXÍ a J. KALINA. J. Pokročilé metody vědecké práce. [online]. [cit. 2020-10-30]. Path: https://www.researchgate.net/publication/ 277775285_Pokrocile_metody_vedecke_prace

MURO, M., L. SIFAN, J. WHITON and S. KULKARNI. Digitalization and the American workforce. [online]. [cit. 2021-02-10]. Path: https://www.brookings.edu/research/digitalization-andthe-american-workforce/

OLECKÁ, I. a K. IVANOVÁ. Metodologie vědecko-výzkumné činnosti [online]. Olomouc: Moravská vysoká škola Olomouc, 2010. ISBN 978-80-87240-33-5. [cit. 2021-01-22]. Path: http://web.ftvs. cuni.cz/hendl/metodologie/41 metodologie_vedecko-vyzkumne_cinnosti.pdf

PIKE, A., H. FARLEY and S. HOPKINS. Digital learning to prison. [online]. [cit. 2021-01-10]. Path: https://www.researchgate.net/publication/311716392_Taking_digital_learning_ to_prison_How_four_universities_are_using_technology_to_deliver_higher_education_ into_prisons_in_Australia_UK_Turkey_and_Nigeria

SMITH, S. Valerie. Exploring the potential of digital technology to reduce recidivism: A Deplhi study on the digitalization of prisons education [online]. 2020 [cit. 2021-02-01]. Path: https:// search.proquest.com/docview/2425893209?pq-origsite=gscholar\&fromopenview=true. Diploma Thesis. Ashford University. Vedoucí práce Dana Shelton.

StatistickáročenkaČeskérepubliky2018 [online]. [cit.2019-11-04]. Path:https://www.czso.cz/ csu/czso/29-soudnictvi-kriminalita-nehody 
Statistická ročenka Vězeňské služby České republiky 2019 [online]. [cit. 2021-01-10]. Path: https://www.vscr.cz/wp-content/uploads/2020/05/Statistická-ročenka-Vězeňské-službyČeské-republiky-za-rok-2019.pdf

ŠÁMAL, P.. Jak se žije za zdmi Valdic: zpovědi nejtěžších zločinců i odborného personálu v nejstřeženější kartuziánské věznici. Praha: Naše vojsko, 2019. ISBN 978-80-206-1810-8.

Vězeňská služba České republiky. Koncepce vězeňství do roku 2025 [online]. [cit. 2019-11-04]. Path:https://www.vscr.cz/wp-content/uploads/2017/06/Koncepce-vezenstvi.pdf 